\title{
EFFECT OF FEEDING DIFFERENT LEVELS OF DATE PITS WITH GROWTH PROMOTERS ON CARCASS CHARACTERISTICS AND MEAT QUALITY MERITS OF NAIMI LAMBS
}

\author{
Ahmed Sami ${ }^{1,2, *}$, Gamaleldin Suliman', Alaeldein Abudabos ${ }^{1}$ and Mutassim Abdelrahman ${ }^{1}$ \\ ${ }^{1}$ Department of Animal Production, College of Food and Agricultural Sciences, King Saud University, 11451 Riyadh, \\ Saudi Arabia; ${ }^{2}$ Department of Animal Production, Faculty of Agriculture, Cairo University, 12613, Giza, Egypt. \\ "Corresponding author's e-mail: assami70@yahoo.com
}

Twenty five three months old Naimi lambs initially weighed $24.53 \pm 0.40$ were used to test the effects of partially replacing barely with $30 \%$ or $50 \%$ crushed date pits (CDP) supplemented with or without a commercial enzyme mixture (CEM) as a natural growth promoter on carcass characteristics, fat deposition and meat quality merits of Naimi lambs. The lambs were randomly divided equally into five groups; control ( $0 \% \mathrm{CDP})$; T1 (30\% CDP); T2 (30\% CDP plus CEM); T3 (50\% CDP); and T4 (50\% of CDP plus CEM). The lambs were slaughtered after three months with final average weight $51.13 \pm 1.69 \mathrm{~kg}$. The carcass characteristics and fat measurements were not significantly different except for liver, body fat and body wall thickness. Liver weights of 50\% CDP (T3) group were significantly $(\mathrm{P}<0.05)$ higher than those of (T2) and (T4) groups. The results showed non-significant differences among the five experimental groups in meat quality merits, but it was noticeable that the control group had lost more liquids on cooking (35.68\%) compared to the other four treatment groups. Significant red color was measured for the (T2) group after 1 hour (18.65) but the (T3) group had the highest red color value (21.63) after 24 hours. It is concluded that replacing barely by CDP as a very cheap energy source up to $50 \%$ fortified with CEM as a growth promoter in Naimi growing lambs diets resulted in acceptable carcass characteristics and meat quality merits. Keywords: Enzyme, crushed date, animal feed, meat quality, small ruminants.

\section{INTRODUCTION}

Many experiments were conducted to investigate the effect of different enzymes on nutrients digestibility of feedstuffs especially when using agricultural by-products containing high fiber and anti-nutrients as reported by Salem et al. (2015) on Barki rams, and Meale et al. (2014) on small ruminant and beef and dairy cattle. The results showed that enzymes can improve feed utilization and animal performance by enhancing dietary fiber digestion which resulted in increase in digestible energy intake. Today, enzymes are widely used in animal nutrition. Addition of enzymes to animal feed results in increased weight gain reduced feed consumption, reduced mortality especially in disease conditions (Beauchemin et al., 2003; Colombatto and Adesogan, 2007). In fact enzymes are finding more usage in modern animal production as they are Eco-friendly and have become a useful replacement for antibiotics as growth promoters.

In most areas of the world corn and barely are the predominant sources of energy in feed due to their abundance and digestibility. Barely form about $60 \%$ from the fattening lamb's diets in Saudi Arabia. Historically high barely prices coupled with short supplies prompting nutritionists to search for other suitable raw materials to provide required nutrients to maintain productivity and to lower feed cost. Date byproducts (discarded dates and pits) are one of these choices based on their nutritional potentialities. The annual total amount of date production in Saudi Arabia is estimated to be 1,031,082 tones (SMOA, 2013). The expected discarded dates are around $20-30 \%$ of the total production according to Babiker (2011). Hence the pits weigh about 10 to $15 \%$ of the fruit (Al-Saiady, 2007); the estimated amount produced of this byproduct is going to be 24,791 to 37,187 tones every year. These date pits contain $5-7 \%$ crude protein, $7-10 \%$ oil and $10-20 \%$ crude fiber (Hadjipanyiotou and Rihani, 2000). This huge amount of date wastes could cause ecological problems if appropriate treatments were not used to enhance their nutritional values. Therefore, several studies were conducted and covered a wide range of animals; poultry (Kamel et al., 1981), and small ruminants (Mahgoub et al., 2007). Also, Al-Dobaib (2009) fed date byproducts to dairy animals. Moreover, Sotolu et al. (2011) fed date palm seeds and fruits to fish.

More researches are required to provide accurate, consistent and economically attractive improvements in livestock productivity by using enzymes as feed additives. It is also, important to investigate the possibility of partially substituting expensive grains as corn and barley which are usually imported at high prices with date pits as an alternative source of energy in lambs' diets. Therefore, the objective of this trail was to evaluate the effects of 
substituting 0,30 and $50 \%$ of barley with crushed date pits (CDP), poor quality feeds, treated with commercial enzyme mixture (CEM) supplementation on carcass characteristics, fat deposition and meat quality merits of Naimi lambs.

\section{MATERIALS AND METHODS}

Lambs and treatments: The three months of the feeding trial of this investigation was conducted at the experimental farm of the animal production department, college of food and agriculture sciences, King Saud University, Saudi Arabia, during the period from the first of January till the end of March 2014. Twenty five three months old Naimi male lambs initially weighed $24.53 \pm 0.40$ were used in this study. The lambs were randomly divided equally into five groups (5 lambs each) where they housed in an individual pen $(0.8 \mathrm{x}$ $1.4 \mathrm{~m})$ with separate feeders and drinkers. Crushed date pits (CDP) with or without a commercial enzyme mixture (CEM) supplementation (Tomoko, a commercial enzyme mixture supplement that contains acidic protease, $\alpha$-amylase, pectinase, phytase, glucoamylase, cellulose and Aspergillus Awamori cells) was partially replaced the barley in the growing lambs' diet. The dietary treatments were: Control ( $0 \%$ CDP); T1 (30\% of CDP); T2 (30\% of CDP plus CEM); T3 (50\% of CDP); and T4 (50\% of CDP plus CEM). The concentrate diets were formulated according to NRC (1994) to cover all nutrient requirements of growing lambs. One $\mathrm{kg}$ per ton was the level of CEM added to T2 and T4 rations. Moreover, lambs were fed the assigned diets for two weeks as an adaptation period followed by three months experimental period. The ingredients used in diets are presented in Table 1.

Carcass characteristics and fat deposition: At the end of the feeding trial, four lambs were randomly selected, weighed and slaughtered according to the Islamic rules, in a commercial abattoir after fasting for $18 \mathrm{~h}$ except for water. The gastrointestinal tract was collected, weighed filled and empty to calculate empty body weight. Weights of hot carcass, heart, liver, spleen, kidneys, omental fat, mesenteric fat and kidneys knob and channel fat (KKCF) were recorded. Body fat thickness over the center of the longissimus dorsi (LD) muscle and body wall thickness $11 \mathrm{~cm}$ lateral to the dorsal process between the $12^{\text {th }}$ and the $13^{\text {th }}$ ribs were also measured. Dressing percentage values were calculated based on the hot carcass and empty body weight.

Meat quality analysis: The meat quality analysis was carried out in the meat labs of the animal production department, college of food and agriculture sciences, King Saud University, Saudi Arabia.

pH and temperature: The meat $p H$ and temperature $(1 \mathrm{hr}$. postmortem) was measured directly by inserting a portable meat $p H$ - Meter (Model: $p H$ 211, Hanna Instruments) into the hot carcass while on rail through an opening between the $12^{\text {th }}$ and $13^{\text {th }}$ ribs after complete dressing. The mean value of two readings was calculated and considered as the initial $\mathrm{pH}_{\mathrm{l}}$ and temperature. The final $\mathrm{pH}_{24}$ was measured after 24 hrs. overnight chilling at $4^{\circ} \mathrm{C}$.

Color: The color values of $L^{*}$ (lightness), $a^{*}$ (redness) and $b^{*}$ (yellowness) were measured in duplicate on the Longissimus dorsi (LD) muscle (on the same day after dressing and while on rail; initial Color $_{l}$ ) and after 24hrs; final Color 24 following 30 minutes blooming period using a Chroma meter (Konica Minolta, CR-400-Japan).

Cooking loss and shear force: The cooking loss was determined using the Longissimus dorsi (LD) muscle. The muscle was cooked to an internal temperature of $70^{\circ} \mathrm{C}$ which was monitored by a thermocouple thermometer probe (Ecoscan Temp JKT, Eutech Instruments). The muscle was weighed before and after cooking to determine cooking loss as the difference between the initial and final weight. The same cooked sample used for cooking loss determination was reused to evaluate shear force according to Wheeler et al. (2005). The sample was cooled to room temperature $\left(21^{\circ} \mathrm{C}\right)$, then three round cores $(1.27 \mathrm{~cm}$ in diameter) were removed from each muscle sample parallel to the longitudinal orientation of the muscle fibers. The cores were

Table 1. Ingredients of the feeding trial diets for Naimi lambs.

\begin{tabular}{|c|c|c|c|c|c|}
\hline Ingredient, \% & Control & $30 \% \mathrm{CDP}^{*}(\mathrm{~T} 1)$ & $30 \%$ CDP + CEM ${ }^{* *}(\mathrm{~T} 2)$ & $50 \%$ CDP (T3) & $50 \%$ CDP + CEM (T4) \\
\hline Barley grain & 78.00 & 54.60 & 54.60 & 39.00 & 39.00 \\
\hline Date pits & 0.00 & 23.40 & 23.40 & 39.00 & 39.00 \\
\hline $\mathrm{SBM}^{* * *}$ & 8.50 & 8.50 & 8.50 & 8.50 & 8.50 \\
\hline Wheat bran & 11.60 & 11.60 & 11.60 & 11.60 & 11.60 \\
\hline Urea & 0.00 & 0.30 & 0.30 & 0.50 & 0.50 \\
\hline $\mathrm{CaCO}_{3}$ & 1.20 & 1.00 & 1.00 & 0.80 & 0.80 \\
\hline Salt & 0.50 & 0.50 & 0.50 & 0.50 & 0.50 \\
\hline Min.+Vit. ${ }^{* * * *}$ & $0.1-0.2$ & $0.1-0.2$ & $0.1-0.2$ & $0.1-0.2$ & $0.1-0.2$ \\
\hline CEM & - & - & One $\mathrm{kg}$ /tone & - & One $\mathrm{kg} /$ tone \\
\hline
\end{tabular}

${ }^{*}$ CDP: Crushed Date Pits, replaced instead of barely by $30 \%$ and $50 \% ;{ }^{* *}$ CEM: Commercial Enzyme Mixture: Tomoko, a commercial enzyme mixture supplement that contains acidic protease, $\alpha$-amylase, pectinase, phytase, glucoamylase, cellulose and Aspergillus Awamori cells; ${ }^{* * *}$ SBM: Soya Bean Meal; ${ }^{* * * *}$ Contained per kg, 10000 IU vitamin A, 1000 IU vitamin D, $20 \mathrm{IU}$ vitamin E, $300 \mathrm{mg} \mathrm{Mg,} 24 \mathrm{mg} \mathrm{Cu}, 0.6 \mathrm{mg} \mathrm{Co,} 1.2 \mathrm{mg} \mathrm{I}, 60 \mathrm{mg} \mathrm{Mn,} 0.3 \mathrm{mg} \mathrm{Se,} 60 \mathrm{mg} \mathrm{Zn}$. 
taken using a handheld coring device. Shear force was determined as the maximum force $(\mathrm{Kg})$ perpendicular to the fibers using a Texture Analyzer (TA-HD-Stable Micro Systems, England) equipped with a Warner-Bratzler attachment. The crosshead speed was set at $200 \mathrm{~mm} / \mathrm{min}$.

Water holding capacity: The water-holding capacity (WHC) was determined following the modification made by Wilhelm et al. (2010). Two replicates of around $2 \mathrm{~g}$ were collected from the $L D$ muscle sample and cut into cubes. Then, the sample was placed between two filter papers and two Plexiglas and left under a $10-\mathrm{kg}$ weight for $5 \mathrm{~min}$. Thereafter, the sample was weighed and WHC ratio was determined as the difference between the initial and final weights.

Statistical analysis: Data on growth performance and carcass characteristics were statistically analyzed by GLM procedures of SAS (2009). Duncan's multiple range test was used to test significant differences between means.

\section{RESULTS}

Carcass characteristics: Carcass characteristics are shown in Table 2. Most of the carcass characteristics were not significantly different except for liver weight. Liver weights of 50\% CDP (T3) group were significantly $(\mathrm{P}<0.05)$ higher than those of $30 \%$ CDP plus enzyme (T2) and 50\% CDP plus enzyme (T4) groups. On the other hand, the control, $30 \%$ CDP (T1) and 50\% CDP (T3) groups were not significantly different. Also (T2) and (T4) groups were not significantly different. The highest value of liver weight $(0.95 \mathrm{~kg})$ was attained by (T3) group, while the lowest $(0.67$ $\mathrm{kg}$ ) was attained by (T2) group.

The slaughter weights and non-carcass components were not significantly $(\mathrm{P}>0.05)$ different between the treatments except for liver, in spite of this the groups with crushed date pits (T3) and crushed date pits plus enzymes (T4) attained additional final weights compared to the rest groups. This was also true for empty body weights. On the other side, the dressing percentages did not follow the same trend as the slaughter weights due to the depressed hot carcass weights.

Fat deposition: The results of fat deposition are presented in Table 3. Most fat deposition results were not significantly different except body fat and body wall thickness. The body fat thickness $(\mathrm{mm})$ differed significantly among the five groups, (T1) group had the highest body fat thickness value $(7.56 \mathrm{~mm})$ compared to the other four groups. While the (T4) group had the lowest body fat thickness value $(5.35 \mathrm{~mm})$. Non- significant differences were detected among the control, (T1), (T2), and (T3) groups. Also, (T4) group did not differ significantly from control, (T2) and (T3) groups. The significant trend was noticed in the body wall thickness (mm), but the highest values (10.89 and $10.17 \mathrm{~mm}$ ) were recorded for the (T2) and (T3) groups, respectively. While the control group had the lowest significant value $(5.84 \mathrm{~mm})$. Groups (T1) and (T4) showed non-significant difference with the other three groups. Including crushed date pits (CDP) in the diets of growing Naimi lambs did not significantly affect fat deposition except for back and body

Table 2. Effects of crushed date pits (CDP) and commercial enzyme mixture (CEM) on carcass characteristics of Naimi lambs.

\begin{tabular}{lcccccc}
\hline Parameter & Control & $\mathbf{3 0 \%}$ CDP & $\mathbf{3 0 \%}$ CDP + CEM & $\mathbf{5 0 \% ~ C D P ~}$ & $\mathbf{5 0 \%}$ CDP + CEM & SEM \\
\hline Slaughter wt. (kg) & 51.00 & 50.57 & 48.67 & 52.87 & 52.53 & 1.69 \\
Empty body wt. (kg) & 46.58 & 45.07 & 44.53 & 48.17 & 48.30 & 1.62 \\
Hot carcass wt. (kg) & 26.00 & 25.87 & 24.73 & 24.97 & 26.30 & 0.83 \\
Dressing (\%) & 55.84 & 57.69 & 55.54 & 51.84 & 54.45 & 1.78 \\
Heart wt. (kg) & 0.20 & 0.20 & 0.19 & 0.21 & 0.18 & 0.01 \\
Liver wt. (kg) & $0.89^{\mathrm{ab}}$ & $0.87^{\mathrm{ab}}$ & $0.67^{\mathrm{c}}$ & $0.95^{\mathrm{a}}$ & $0.79^{\mathrm{bc}}$ & 0.04 \\
Spleen wt. (kg) & 0.09 & 0.06 & 0.08 & 0.08 & 0.08 & 0.12 \\
Kidneys wt. (kg) & 0.13 & 0.13 & 0.13 & 0.13 & 0.13 & 0.01 \\
\hline
\end{tabular}

${ }^{\mathrm{a}, \mathrm{b}, \mathrm{c}}$ Means with different superscript in the same row differ significantly $(\mathrm{P}<0.05)$.

Table 3. Effects of crushed date pits (CDP) and commercial enzyme mixture (CEM) on fat deposition of Naimi lambs.

\begin{tabular}{|c|c|c|c|c|c|c|}
\hline Parameter & Control & $30 \%$ CDP & $30 \%$ CDP + CEM & $50 \%$ CDP & $50 \%$ CDP + CEM & SEM \\
\hline Omental fat wt. (kg) & 0.63 & 0.87 & 0.90 & 1.00 & 0.87 & 0.19 \\
\hline Mesentery fat wt. (kg) & 0.37 & 0.57 & 0.43 & 0.50 & 0.53 & 0.07 \\
\hline $\mathrm{KKC}^{*}$ fat wt. (kg) & 0.32 & 0.44 & 0.39 & 0.47 & 0.43 & 0.11 \\
\hline Backfat thickness (mm) & $5.60^{\mathrm{ab}}$ & $7.56^{\mathrm{a}}$ & $6.95^{\mathrm{ab}}$ & $5.61^{\mathrm{ab}}$ & $5.35^{\mathrm{b}}$ & 0.58 \\
\hline Body wall thickness (mm) & $5.84^{\mathrm{b}}$ & $7.63^{\mathrm{ab}}$ & $10.89^{\mathrm{a}}$ & $10.17^{\mathrm{a}}$ & $9.45^{\mathrm{ab}}$ & 1.14 \\
\hline
\end{tabular}

*KKC: Kidneys, Knob and Channel fat; ${ }^{\mathrm{a}, \mathrm{b}}$ Means with different superscript in the same row are differ significantly $(\mathrm{P}<$ $0.05)$. 
Sami, Suliman, Abudabos \& Abdelrahman

Table 4. Effects of crushed date pits (CDP) and commercial enzyme mixture (CEM) on meat quality merits of Naimi lambs.

\begin{tabular}{|c|c|c|c|c|c|c|}
\hline Parameter & Control & $30 \%$ CDP & 30\% CDP + CEM & $50 \%$ CDP & $50 \%$ CDP + CEM & SEM \\
\hline WHC* & 0.44 & 0.41 & 0.42 & 0.40 & 0.42 & 0.02 \\
\hline Cooking Loss (\%) & $35.68^{\mathrm{a}}$ & $31.15^{\mathrm{b}}$ & $32.29^{\mathrm{ab}}$ & $28.78^{\mathrm{b}}$ & $30.92^{\mathrm{b}}$ & 1.26 \\
\hline $\mathrm{SF}(\mathrm{kg}) * *$ & $2.66^{\mathrm{b}}$ & $3.60^{\mathrm{ab}}$ & $2.85^{\mathrm{b}}$ & $2.81^{\mathrm{b}}$ & $4.80^{\mathrm{a}}$ & $\begin{array}{l}0.41 \\
0.26\end{array}$ \\
\hline $\operatorname{IMT}_{1 \mathrm{~h}}\left({ }^{\circ} \mathrm{C}\right)^{* * *}$ & $29.35^{\mathrm{b}}$ & $29.93^{b}$ & $30.85^{\mathrm{a}}$ & $30.95^{\mathrm{a}}$ & $31.55^{\mathrm{a}}$ & \\
\hline$p H_{l h}$ & 6.12 & 6.22 & 6.05 & 6.07 & 5.82 & 0.13 \\
\hline $\mathrm{pH}_{24 h}$ & 5.89 & 5.94 & 5.94 & 5.91 & 5.93 & 0.03 \\
\hline$L^{*}{ }_{1 \mathrm{~h}}$ & 39.20 & 37.38 & 37.74 & 38.72 & 38.74 & 2.20 \\
\hline$a^{*}{ }_{1 \mathrm{~h}}$ & $17.77^{\mathrm{ab}}$ & $18.40^{\mathrm{a}}$ & $18.65^{\mathrm{a}}$ & $16.01^{\mathrm{ab}}$ & $15.07^{b}$ & 0.96 \\
\hline$b^{*}{ }_{1 \mathrm{~h}}$ & 5.93 & 5.24 & 6.42 & 4.73 & 5.01 & 0.63 \\
\hline$L_{24 \mathrm{~h}}$ & 40.95 & 40.60 & 44.18 & 43.78 & 42.30 & 1.39 \\
\hline$a *_{24 \mathrm{~h}}$ & $19.82^{\mathrm{ab}}$ & $17.88^{\mathrm{b}}$ & $19.62^{\mathrm{ab}}$ & $21.63^{\mathrm{a}}$ & $19.90^{\mathrm{ab}}$ & 0.92 \\
\hline
\end{tabular}

wall fats. Generally, the treatment groups revealed hour (15.07) and for the (T1) group after 24 hour (17.88). noticeable increase in fat accretion with inclusion of CDP compared to the control group.

Meat quality: The results of the effects of substitution of barley with CDP by $30 \%$ without enzyme and $50 \%$ with enzyme supplementation on the physical meat quality merits of Naimi lambs are presented in Table 4. There were no significant differences among the five experimental groups in water holding capacity (WHC), $p H_{1 h}, p H_{24 h r s}, L^{*}{ }_{1 \mathrm{~h}}$ value, $b{ }^{*}$ hvvalue, $L^{*}{ }_{24 h r s}$ value, and $b *_{24 h r s}$ value. On the contrary, the control group lost more liquids during cooking (35.68\%) compared to the other four groups. The only significant difference between control and other four groups was detected with the (T2) group. In this study, the inclusion of crushed date pits in diets of growing lambs enhanced the ability of meat to hold water which in turn lead to significant $(\mathrm{P}<0.05)$ decrease in moisture loss on cooking. The lowest cooking loss percentage (28.78\%) was recorded for the (T3) group. The control group was the tenderest group compared to its counterparts, where it has the lowest shear force value $(2.66 \mathrm{~kg})$. The (T1), (T2) and (T3) groups had the same meat tenderness as the control group. The (T4) group that had the highest shear force value $\left(4.80 \mathrm{~kg} / \mathrm{cm}^{2}\right)$, was the toughest group. Significant differences were observed between (T4) and control, (T2) and (T3) groups. Regarding the internal meat temperature after 1 hour from slaughter, no significant differences were detected between the control and (T1) groups (averaged $29.64^{\circ} \mathrm{C}$ ). The other three groups had significant higher meat temperature (averaged $30.00^{\circ} \mathrm{C}$ ) compared to the control and (T1) groups. The meat redness values $\left(a^{*}\right)$ were significantly differed among the five groups either after 1 hour from slaughter or after 24 hours. The more red color was measured for the (T2) group after 1 hour (18.65) but the (T3) group had the highest red color value (21.63) after 24 hours. On the other hand, the pale red color (the lowest $a^{*}$ value) was recorded for the (T4) group after 1

There were non-significant differences among the control, (T1), (T2) and (T3) groups in red color value after 1 hour of slaughter. While after 24 hours, the control, (T2), (T3) and (T4) groups were not significantly different.

\section{DISCUSSION}

The results of carcass characteristics in the current study are in line with Suliman and Mustafa (2014) who reported a significant increase in total gain and final body weight of growing lambs as a result of partial substitution of ground maize with ground date pits. Similarly, Al-Shanti et al. (2013) reported an increase $(\mathrm{P}>0.05)$ in final body weight and insignificant differences between the treatments in all non-carcass components when crushed date seeds were used for feeding Assaf lambs. Lakhdara et al. (2013) concluded that incorporation of date seeds in a ration based on wheat straws and concentrates has a positive influence on the improvement of sheep daily gain and final body weights. On the contrary, Abdel-fattah et al. (2012) found a decrease in final body weight when ground date palm replaced ground yellow corn in feeding diets of Barki lambs.

On the other hand, the noticeable increase in fat accretion with inclusion of CDP compared to the control group in the present study is in agreement with that reported by Al-Shanti et al. (2013).

The non-significant effects of feeding crushed date pits on meat quality are in agreement with Sami et al. (2010) who found that feeding crushed date pits had no adverse effects on the carcass characteristics and meat quality traits of Najdi lambs. Sujani and Seresinhe (2015) concluded that supplementation of exogenous enzymes with ruminant diets shows beneficial effects on production performance in ruminant animals though some debatable issues need to be further investigated. Therefore, future studies are highly 
recommended with the special emphasis on feed specific enzyme activity, method of supplementation and optimum dosage of enzymes.

In conclusion, substituting barely with crushed date pits as a poor down grade quality feedstuff and inexpensive energy source up to $50 \%$ enhanced with a commercial enzyme mixture as a natural growth promoter in Naimi growing lambs diets resulted in acceptable carcass characteristics and meat quality merits.

Acknowledgment: The authors gratefully acknowledge The Deanship of Scientific Research, King Saud University for supporting this research.

\section{REFERENCES}

Abdel-Fattah, M.S. Afaf, A. Abdel-Hamid, A.M. Ellamie, M.M. El-Sherief and M.S. Zedan. 2012. Growth rate, some plasma biochemical and amino acid concentrations of Barki lambs fed ground fate palm at Siwa Oasis, Egypt. American-Eurasian J. Agric. Environ. Sci. 12:1166-1175.

Al-Dobaib, S.N., M.A. Mehaia and M.H. Khalil. 2009. Effect of feeding discarded dates on milk yield and composition of Aradi goats. Small Rumin. Res. 81:167170 .

Al-Saiady, M.Y. 2007. Agricultural by-products. Scientific meeting: Environmental effects of agricultural byproducts and means of uses. King Abduaziz City for Science and Technology, Riyadh, Saudi Arabia.

Al-Shanti, H.A., A.M. Kholif, K.J. Al-Shakhrit, M.F. AlBanna and I.E. Abu Showayb. 2013. Use of crushed date seeds in feeding growing Assaf lambs. Egypt. J. Sheep Goat Sci. 8:65-73.

Babiker, E.A. 2011. Date byproducts. The $2^{\text {nd }}$ A-Qassim Agricultural Forum, Directorate of Animal Wealth, Ministry of Agriculture, Saudi Arabia.

Beauchemin, K.A., D. Colombatto, D.P. Morgavi and W.Z. Yang. 2003. Use of exogenous fibrolytic enzymes to improve feed utilization by ruminants. J. Anim. Sci. $81: 37-47$.

Colombatto, D. and A.T. Adesogan. 2007. Applications of cell wall degrading enzymes as additives for ruminant feeds, Chap. 3. In: I. Givens (ed.), Polysaccharides and polysaccharidases in food and agriculture. Research Signpost, India.

Hadjipanayiotou, M. and N. Rihani. 2000. The potential of using non-conventional feed resources during dry years in the Mediterranean region. EAAP publication 94:107115 .

Kamel, B.S., M.F. Diab, M.A. Ilian and A.J. Salman.1981. Nutritional value of whole dates and date pits in broiler rations. Poult. Sci. 60:1005-1011.
Lakhdara, N., H. Bererhi, A.L. Dib and O. Bouaziz. 2013. Effect of the incorporation of date pits in a diet composed of wheat straw and concentrate on daily gain weight of local sheep (Ouled Djellal). Arch. App. Sci. Res. 5:164-166.

Mahgoub, O., I.T. Kadim, M.H. Al-Busaidi, K. Annamalai and N.M. Al-Saqri. 2007. Effects of feeding ensiled date palm fronds and a byproduct concentrate on performance and meat quality of Omani sheep. Anim. Feed Sci. and Tech. 135:210-221.

Meale, S.J., K.A. Beauchemin, A.N. Hristov, A.V. Chaves and T.A. McAllister. 2014. Opportunities and challenges in using exogenous enzymes to improve ruminant production: Board-invited review. J. Anim. Sci. 92:427-442.

NRC. 1994. Nutrient Requirements of Poultry, 9 ${ }^{\text {th }}$ Rev. Ed. National Research Council; National Acad. Press, Washington, DC.

Salem, A.Z.M., H. Alsersy, L.M. Camacho, M.M. El-Adawy, M.M.Y. Elghandour, A.E. Kholif, N. Rivero, M.U. Alonso and A. Zaragoza. 2015. Feed intake, nutrient digestibility, nitrogen utilization, and ruminal fermentation activities in sheep fed Atriplex halimus ensiled with three developed enzyme cocktails. Czech J. Anim. Sci. 60:185-194.

Sami, A., A. Al-Owaimer, S. Zahran and M. Koohmaraie. 2010. Performance, carcass and meat quality traits of Najdi lambs fed saltbush and date pits. J. Appl. Anim. Res. 38:77-80.

SAS. 2009. Institute Inc. SAS Users Guide: Version 7.0. SAS Institute Inc., Cary, NC.

SMOA. 2013. Yearly Agricultural Statistical Book, No. 49. Saudi Ministry of Agriculture, Saudi Arabia.

Sotolu, A.O., A.A. Kigbu and J.A. Oshinowo. 2011. Nutritional evaluation of date palm (Phoenix dactylifera) seeds and fruit as source of feeds in aquaculture. Electr. J. Environ. Agric. Food Chem. 10:2279-2285.

Sujani, S. and R.T. Seresinhe. 2015. Exogenous enzymes in ruminant nutrition: A review. Asian J. Anim. Sci. 9:8599.

Suliman, A.I.A. and S.M.S. Mustafa. 2014. Effects of ground date seeds as a partial replacer of ground maize on nitrogen metabolism and growth performance of lambs. Egypt. J. Sheep Goat Sci. 9:23-31.

Wheeler, T.L., S.D. Shackelford and M. Koohmaraie. 2005. Shear force procedures for meat tenderness measurement. Meat Animal Research Center, Agricultural Research Service, United States Department of Agriculture, Clay Center, NE 68933 USA.

Wilhelm, A.E., M.B. Maganhini, F.J. Hernandez-Blazquez, E.I. Ida and M. Shimokomaki. 2010. Protease activity and the ultrastructure of broiler chicken PSE (pale, soft, exudative) meat. Food Chem. 119:1201-1204. 
Sami, Suliman, Abudabos \& Abdelrahman 